\title{
Analysis of the Dynamic Mechanism of China's Electric Power Regulatory System Change: Based on the Concept of National Leaders
}

\author{
Yong-qi ZHANG \\ The second Campus of North China Electric Power University \\ Baoding, Hebei, China
}

Keywords: Power Supervision System; National Leader Concept; Role Process.

\begin{abstract}
Electricity is the basic industry of the national economy to supervise electricity. It's not only the development of electricity itself, but also the operation and development of the national economy. The reform of the power supervision system is an important task for the Chinese government to strengthen power management and enhance the level of economic development. This paper mainly uses the research method of logic analysis to explain the macro-political and economic system generated by the national leaders' ideas in different historical periods in the power industry supervision system.
\end{abstract}

\section{Introduction}

The power industry is an important basic industry related to the national economy and the people's livelihood. According to the industrial chain, it can be divided into four links: power generation, transmission, distribution, and power sales. Because of the huge investment in the power industry, strong asset specificity, and significant characteristics of economies of scale, it has long been considered a natural monopoly industry. Most countries in the world basically adopt state-owned power generation, transmission, distribution, and power sales, and implement vertical monopoly operation model and strict supervision. Based on the concept of national leaders and the concept of the country's leaders, this paper fully combines the country's institutional environment and the degree of progress in the reform of power marketization, combining with the marketoriented reform of the power industry and the status quo of the power industry, to explain its impact on the changes in China's power regulatory system.

\section{The History of China's Power Regulatory System Changes}

\subsection{Management system under the planned economy (1949-1978)}

In the early days of the founding of the People's Republic of China, China's power industry implemented a planned management system for state monopoly operations. The national electric industry management department not only fulfilled the functions of formulating industrial policies and industry plans, but also implemented integrated vertical operation management for the entire industry. Such a management system has the characteristics of no distinction between government and enterprise, macro management and micro management. Its typical performance is that the country unifies the power infrastructure construction and unifies the national electricity price, and the power price lacks the function of reflecting market signals, which further leads to the unreasonable allocation of resources; the lack of business autonomy and the lack of technological innovation; the contradiction between power supply and demand is prominent. Electricity has become a bottleneck that restricts the healthy development of the economy. For quite a long period of time, the Chinese government adopted the monopoly mode of operation of the power industry in which the state invests and operates exclusively. The power production, transmission, and distribution functions are concentrated in one department. There is no independent power producer, and the power management model is a vertically integrated monopoly mode [1]. 


\subsection{Power Management System during the Period of Reform and Exploration (1979-1997)}

Since the Third Plenary Session of the Eleventh Party in 1978, China's power industry system has entered a period of reform and exploration. During the second period, the Ministry of Power Industry was established, the Ministry of Water Resources and Electric Power was established for the second time, the Ministry of Energy was established, and the Ministry of Power Industry was established for the third time. The reform of the electric power industry system and the development of the electric power industry require the corresponding reform of the electric power investment system. During this time, the biggest change in the electric power construction investment system has been transferred from funding to loans; insufficient investment has mainly taken measures such as the establishment of a power construction fund, the right to use electricity and electricity, and the fund raising office. In order to save investment, in the construction of electric power, general reductions in construction costs have been carried out and the construction period has been shortened; investment in contractual responsibility systems and bidding systems for capital construction projects have been invested.

The characteristics of the reform in this period were mainly the central government's partial innovation of the regulatory system, the creation of investment incentives in the power generation market through the relaxation of market access on the power generation side and the reform of the on-grid tariff system to attract investment. It is the mandatory institutional change of the power management system by the central government to resolve power shortages, and it is also combined with the inducement change method. For example, investment benefit policy makes use of profit opportunities to encourage people to voluntarily change old systems, support the new system and establish a new system. However, in the strict sense, it was only the changes in the power management system and the margin.

\subsection{A new power management system oriented to the marketization of the power industry (1997-present)}

The beginning of this phase is marked by the establishment of the State Power Corporation. After more than 20 years of exploration, at least on the power generation side, a number of powergenerating patterns have been formed, and the conditions for introducing competition among power generation companies are basically available. The reform of the power system is mainly to discuss the power reform with the introduction of market competition mechanism as the main content.

The characteristics of this period of reform, this is a compulsory institutional change led by the central government with the goal of separating government and enterprises and market-oriented pilots. Overall, it has achieved certain effects. China's power regulatory system has formed a new pattern. The State Power Corporation has become a directly affiliated enterprise of the State Council, exercising corporate functions and being responsible for the operation of state-owned power assets. Although the State Power Corporation no longer has administrative functions, it still maintains a vertically integrated monopoly..

\section{The Dynamic Mechanism Analysis of Each Change}

\subsection{Management system under the planned economy (1949-1978)}

\subsubsection{Ministry of Fuel Industry (1949-1955)}

During this period, the idea of the state leaders was mainly to consolidate the political power. After the founding of New China, the country is transitioning from a new-democratic society to a socialist society. There is a considerable part of the Kuomintang remnants in the country. It is still an important task to pursue the enemy. Electricity is also the lifeblood of the national economy. Therefore, it uses military supervision and management of electricity. In 1949, the Chinese government established the Ministry of Fuel Industry to uniformly manage the oil, coal and power industries. At that time, the Ministry of Fuel Industry was only responsible for the North China 
Electric Power Company and its subsidiaries such as Beijing, Tianjin and Tang. The power industry in other regions was managed by the local military control committee. From January 1994 to the end of 1952, after three years of restoration of the national economy, the power of the local military control committees gradually concentrated into the Ministry of Fuel Industry. In 1905, under the Ministry of Fuel Industry, the General Administration of Electricity was set up. The overall responsibility for power generation, transmission, distribution and sale of electricity was closely followed by the establishment of six regions in the northeast, north, east, south, southwest, and northwest [2].

\subsubsection{Ministry of Power Industry (1955-1958)}

During this period, the concept of the national leaders was mainly to establish a relatively complete socialist system. All the affairs of the country moved closer to socialism. In 1953, the first five-year plan was formulated and implemented, and three major reforms were initiated. In 1954, the first constitution of the new China was promulgated. In 1955, the Ministry of Coal Industry, the Ministry of Power Industry and the Ministry of Petroleum Industry were established, and the Ministry of Fuel Industry was cancelled. The newly established Ministry of Power Industry has undertaken the management function of the Ministry of Fuel Industry for the power industry. Under the Ministry of Power Industry, there are three departments: the Power Design Bureau, the Infrastructure Engineering Administration, and the Hydropower and Power Engineering Bureau. At the same time, the State Administration of Electricity and the six regional electric power administrations are revoked, and the power industry of each province (city, autonomous region) is powered by electricity, which is directly managed by the Ministry of Industry. In 1965, it gradually established and enriched the provincial (city, autonomous region) electric industry management institutions, and formed a management structure with central and local management and central management.

\subsubsection{Ministry of Water Resources and Electric Power (1958-1966)}

During this period, the main idea of the state leaders was to accelerate the construction of a socialist society. Decentralization is carried out, and all regions and industries are encouraged to work hard, strive for the upper reaches, and build socialism more quickly and better. The Nanning Conference in 1958 identified the power development policy for the water main fire. In line with this, the Ministry of Water Resources and the Ministry of Power Industry merged to form the Ministry of Water Resources and Electric Power to speed up hydropower construction. After that, the management power of the power companies was delegated to the provinces (municipalities and autonomous regions), and local self-government was implemented. The Ministry of Water Resources and Electric Power only governed the Beijing-Tianjin-Tangshan Power Grid and the Northeast Power Grid. This period is the period when the power system is most concentrated from concentration to dispersion.

\subsubsection{The period of the Cultural Revolution (1966-1978)}

During this period, the main idea of the state leaders was to continue the revolution under the dictatorship of the proletariat and to remove the influence of capitalist ideas at home. During the Cultural Revolution, the Ministry of Water Resources and Electric Power implemented military control between 1967 and 1970, and decentralized power management to local governments. After the end of the military management, it was taken over by the Revolutionary Committee of the Ministry of Water Resources. After this period, places such as the Administration of Electric Power Administration, design institutes, and power scientific research institutions were decentralized, the power survey and design, scientific research institutions, and electric facilities suffered great damage, and electric power accidents were frequent and power shortages were aggravated. In 1975, the Ministry of Water Resources and Electricity was cancelled by the revolutionary committee and the establishment of the former Ministry of Water Resources and Electric Power was restored. As a result, the management system of China's power industry has reverted to the centralized 
management of the central government and the fragmented management of regional power management departments.

\subsection{Power management system during the period of reform and exploration (1979-1997)}

\subsubsection{The second establishment of the Ministry of Electric Power Industry and the Ministry of Hydraulic Power (1979-1988)}

During this period, the main idea of the state leaders was to carry out market-oriented reforms and expand the autonomy of business operations. In May 1979, the Ministry of Electric Power proposed adjustment, reform, rectification, and improvement. The reform plan has clearly defined the principle that the electric power industry must precede the development of the national economy and requires the implementation of a highly centralized management policy. During the period, two changes took place: in February 1979, the Ministry of Water Resources and Electric Power was cancelled, the Ministry of Water Power and the Ministry of Water Resources were established for the second time; in 1982, the Ministry of Water Resources and the Ministry of Power Industry were merged again, and the Ministry of Water Power was established for the second time. During this period, the Central Government made the decision to expand the autonomy of enterprises. The government has granted 14 operating rights such as production autonomy, raw material purchasing rights, labor rights, and sales rights to enterprises, and the relationship between the state and the enterprises Adjustments have been made. In 1983, according to the report of the Party Committee of the Chinese Communist Party's Ministry of Water Resources and Ministry of Water Resources on improving the proportion of investment in electricity, the central government proposed to fully mobilize and exert the enthusiasm of power generation in all regions, departments and units, to break the practice of power supply in one power department to accelerate electricity industrial development. [3]

\subsubsection{Established the Ministry of Energy and China Electric Power Enterprise Association (1988-1993)}

During this period, the main idea of the state leaders was to adjust the relationship between the government and the enterprise and separate the government from the enterprise. On May 22, 1988, the Ministry of Energy was formally established. In December of the same year, the China Electric Power Enterprise Association was established. On the basis of the Provincial Power Administration Bureau and the Power Industry Bureau, Electric Power Group Corporation and Provincial Power Corporation were established. As a result, the initial separation of the administrative management, corporate management, and industry self-regulatory management functions of the power industry was achieved, and a solid step was taken in the reform of the power management system.

\subsubsection{The third establishment of the Ministry of Power Industry (1993-1997)}

During this period, the main idea of the state leaders was to establish a modern enterprise system and play the role of the capital market. Due to lack of electricity, insufficient capital construction by the central government, and inefficiency in the power industry, the government has reformed the power system in terms of liberalizing investment access and allowing enterprises to operate independently. State-owned power companies have tried programs such as contract responsibility system and simplified government decentralization. During the Ministry of Power Industry, there was no significant change in the reform of the power industry system..

3.3 A new type of power management system oriented to the marketization of the power industry (1997-present)

\subsubsection{Taking the province as an entity (1997-2002)}

During this period, the main idea of the state leaders was to adjust the relationship between government and enterprises, and between central and local power. The main performance is to give full play to the role of the market, separate government and enterprises, and implement the province as a pilot. The reform at this stage is the second milestone in the reform of the power industry. The 
focus of the reform is to separate the administrative functions of the government from the functions of the business and to make the province an entity. In 1989, the former State Power Corporation implemented the separation of plant and network. It also used Shandong, Shanghai, Shanghai and other provinces and cities as pilot units for the electricity market. During this period, the State Power Corporation was the only purchaser. While the state is opening up the power generation market, the State Grid Corporation itself has a large number of power plants, which is easy to squeeze independent power producers, resulting in intranet power plants and networks.

\subsubsection{Electricity Regulatory Commission (2002-present)}

During this period, the main ideas of the state leaders were: striving for a peaceful environment, vigorously developing the economy, and aligning with the world. In February 2002, a notice on the reform of the power system was issued, and the reform requirements for the construction of the market economy system were clearly put forward. The document clarifies the reform requirements for transforming government functions, improving the government's macroeconomic regulation and control, and strengthening the regulation of the electricity market. It is required to formally separate the government's power regulatory function from the macro-control function. At the same time, the State Council has put forward the requirements for the establishment of the State Electricity Regulatory Commission, and it is clear that the agency is a directly affiliated institution of the State Council and performs its power supervision duties in accordance with the state's authorization. At the beginning of this stage, the national power company split, the power generation was separated from the power grid, and multiple entities were formed on the power generation side. The power grid company was a single purchaser, forming a single market model for generating and distributing buyers.

\section{Conclusion}

The improvement and development of the power regulatory system requires the joint efforts of all parties. Only by clarifying the powers and responsibilities of the National Energy Administration, the National Development and Reform Commission, the State-owned Assets Supervision and Administration Commission, the environmental protection department and the local power regulatory authorities, and defining their respective work boundaries, the overall governance of the power regulatory system can be targeted, and the functions between the various departments can exert their maximum effectiveness. At the same time, the social supervision forces represented by the China Electricity Council and related power environmental protection organizations also need to be integrated accordingly, in order to truly play their social supervision functions.

\section{References}

[1] Ma Wenbo. Research on the overall governance of power regulation system in Jilin Province [D]. Jilin University, 2017. (In Chinese)

[2] Cao Liyuan, He Yunzheng. The Past, Present and Future of China's Electric Power Regulatory System Reform [J]. Journal of North China Electric Power University (Social Science Edition), 2017 (02): 27-31. (In Chinese)

[3] Wang Wei. The Reform Path of China's Electric Power Supervision System under the Reform of New Electricity [J]. Journal of the Party School of the CPC Central Committee, 2016, 20 (05): 108-112. (In Chinese) 